\title{
Investigating the Relationship between the Social and Economic-financial Performance
}

\author{
Giovanni Vaia ${ }^{1}$, Marco Bisogno ${ }^{2}$, Aurelio Tommasetti ${ }^{2}$ \\ ${ }^{1} \mathrm{Ca}$ ' Foscari University Venice, Venice, Italy \\ ${ }^{2}$ University of Salerno, Fisciano, Italy \\ Correspondence: Giovanni Vaia, Ca' Foscari University Venice, Venice, Italy.
}

Received: November 7, 2016

Accepted: December 23, $2016 \quad$ Available online: January 4, 2017

doi:10.11114/afa.v3i1.2126

URL: http://dx.doi.org/10.11114/afa.v3i1.2126

\begin{abstract}
Hundreds of studies have explored and measured financial returns related to social performance (Margolis and Walsh, 2003), with controversial results. In addition to these studies' outcomes, we found, in this body of literature, a lot of innovation in the integration and adaptation of financial analysis tools and models to the study of statistical relationships.

In this paper, we investigate the relationship between corporate social performance and corporate financial (and economic) performance, using multiple measures of financial and social performance and by looking statistically at the movement of actual financial and social performance over time. We emphasize the worth of statistical analysis in traditional financial representations.

Our findings show how ratio analysis and statistical cause-and-effect validation are not alternatives for developing the financial analysis of sustainability and reporting. We show, through constant testing and a double learning process, the critical relationship between the key factors of financial, economic and social performance.
\end{abstract}

Keywords: social performance, financial performance, corporate social responsibility

\section{Introduction}

In the last decade, Corporate Social Responsibility' projects have received an increased interest from many companies who are looking at their advantages in terms of brand image, new investments, better reputation and customer loyalty. Research has shown how business strategies rooted in social causes can create a virtuous circle seen in the value created in the local community, the satisfaction of its stakeholders, the company reputation and the company sustainability (in the long term). In other words, the value is continuously created and enforced by mutual relationships.

However, social and responsible investments are not free from the possibility of failure and incorrect implementation; these problems can neutralize the normally positive impact on the business and on the firm's overall performance.

Today, companies need to focus on different levels - economic, social and environmental - trying to maintain a balance in the short, medium and long term. Many scholars and practitioners, in recent years, have discussed the need for organizations to guarantee their own economic sustainability through profit and reinvestment into human and social spheres as well as into the protection of the planet. But is this always a good tactic?

Plenty of empirical studies have explored the relationship between Corporate Social Performance (CSP) and Corporate Financial Performance (CFP). Some of them found a negative relationship (Wright and Ferris, 1997), some found no relationship (McWilliams and Siegel, 2000), while others still found a positive relationship (Orlitzky et al., 2003). Many scholars (Margolis and Walsh, 2003; Barnett, 2007) have claimed that we cannot conclude, after years of study, if investments into social causes return benefits to stakeholders. The debate remains unresolved (Margolis and Walsh, 2003).

Although research indicates that any causal effect of social performance on economic performance is likely to be small and difficult to detect with common measures, we argue that the better a firm's social performance, the better it can attract resources (capital, human) and market its products and services. According to Porter and van der Linde (1995), social responsibility is a source of competitive advantage. Barnett (2007), building on the premise of the instrumental 
stakeholder theory that social responsibility can be beneficial to firms, developed the concept of SIC (Stakeholder Influence Capacity), which he defined as 'the ability of a firm to identify, act on, and profit from opportunities to improve stakeholder relationships through CSR [corporate social responsibility]'. Simply, SIC is a formalization of the basic logic that stakeholders view some firms as more credible than others and reward firms accordingly for their acts of social responsibility. Despite the fact that spending on social performance is costly, firms that have accrued adequate SIC through significant social performance may earn financial returns that offset and come to exceed the costs (Barnett and Salomon, 2012). Firms, through increasing levels of social performance, become more likely to gain and profit from improved stakeholder relations, and so an inflection point in financial performance occurs. Firms with the greatest social performance possess a superior capacity to transform social investment into positive financial returns, generating an upward slope in financial returns (Barnett and Salomon, 2012).

In this paper we contribute to the debate on the relationship between social and economic-financial performance. We examine the relationship between corporate social performance and corporate financial (and economic) performance; this investigation reflects a consistency of financial measures that uses multiple measures of social performance, and looks statistically at the movement of actual financial and social performance over time. We try to depict the main principle of cause and effect between them, to answer the following research question: how can we frame and represent the relationship between social and financial performance integrating statistical and financial tools?

In the next sections, we present an analysis of a sample of 275 firms from 2010 to 2014 with 1,375 firm-year observations; the analysis provides a visual representation of cause-and effect patterns on social and financial performance, thusly contributing to the construction of a systematic approach. In doing so, we emphasize the worth of statistical analysis and its integration into traditional financial representations.

Our findings show how ratio analysis and statistical cause-and-effect validation are not alternatives for developing the financial analysis of sustainability and reporting. We show, through constant testing and a double learning process, the critical relationship between the key factors of financial, economic and social performance, and how these factors can be identified and organized for immediate use.

\section{Social Performance and Financial Performance: Antecedents and Recent Developments}

Hundreds of studies explored and measured the financial returns related to social performance (Margolis and Walsh, 2003). The unchanged basic research question is: to what degree is CSR related to traditional financial performance?

According to the traditionalists' hypothesis, social responsibility implies that business managers 'must act in some way that is not in the interest of his employers' (Friedman, 1970). Managers are experts in producing and delivering products and/or services, so they do not necessarily possess expertise in managing social projects. In accordance with Friedman, managers have no business advantage when implementing social programs. Managers, acting as agents of the shareholders, have no mandate to embark on socially-responsible projects that do not enhance the income generating ability of the firm. By pushing a social mission, they reduce a firm's ability to maximize shareholder value; as a result, CSP and CFP are necessarily negatively related. Friedman (1970) saw CSP as an agency problem whereby managers were misallocating shareholder wealth to pursue a social mission of their choosing.

However, Friedman (1970) noted that a firm's investment in social responsibility could 'make it easier to attract desirable employees, it may reduce the wage bill or lessen losses from pilferage and sabotage or have other worthwhile effects.' According to Barnett and Salomon (2012), 'he provided a basis for the counter-argument of stakeholder theorists that CSP and CFP are positively related'.

This view has been expanded by the stakeholder theory (Freemen, 1984), which argues that managers have a responsibility to shareholders - the owners of the corporation - to maximize firm value, and that the better they satisfy stakeholder's interest, the more successful the firm will be in the long run. Engaging in socially responsible behaviors is one of the primary mechanisms through which a firm may foster and maintain trusting stakeholder relationships, reducing the transaction costs of those relationships (Wicks, Berman, and Jones, 1999). Since 1972, a myriad of studies has divided the scientific community, creating skepticism and confusion (Margolis and Walsh, 2003). Methodologies and variables to test such associations are numerous. Hundreds of published empirical studies have tested the relationship between various types of CSP and CFP. Barnett (2007, p. 794) asserts 'that after more than thirty years of research, we cannot clearly conclude whether a one-dollar investment in social initiatives returns more or less than one dollar in benefit to the shareholder'. Studies present different ways to measure CSR (annual report disclosure versus reputational index), different ways to measure financial performance (market returns versus financial accounting measures), and different timescales ${ }^{1}$.

Some scholars have found a negative relationship (Vance, 1975; Wright and Ferris, 1997), others posit that CSP and

${ }^{1}$ For instance see Belkaoui (1976) and Sturdivant and Ginter (1977). 
CFP have a mixed relationship (Cochran and Wood, 1984; Hillman and Keim, 2001) or no significance (McWilliams and Siegel, 2000; Patten, 1991). Still many others have found a positive relationship (Orlitzky et al., 2003).

Beyond past research outcomes, we found a lot of innovation in the integration and adaptation of financial analysis tools and models to the study of statistical relationships. Indeed, the vast majority of social investments are not built on statistical relationships (Castro and Chousa, 2006). Castro and Chousa (2006) support the idea that 'the ratio or mathematical relationship between two quantities is of paramount importance in financial analysis as it injects a qualitative measurement, precisely demonstrating the adequacy of one key financial statement item as compared against another and providing comparisons between companies in the same industry as well as year-to-year comparisons within a single company'.

Barnett and Salomon (2006), Brammer and Millington (2008) and McWilliams and Siegel (2000), for instance, provided some support for the existence of a statistical relationship between some types of CSP and CFP. They focused on the firm-level relationship between CSP and CFP (Brammer and Millington, 2008; McWilliams and Siegel, 2001) or the investment portfolio (Barnett and Salomon, 2006), and likewise found that the highest and lowest levels of CSP were associated with the highest levels of CFP, hypothesizing in some cases a U-shaped relationship (while others assume a more linear correlation).

Unfortunately, we are still suffering from a systematic application of statistical analysis and representations, integrated with primary tools of (qualitative and quantitative) financial analysis, due to a lack of awareness of the main principle of cause and effect (Castro and Chousa, 2006). Most analysts have given equal weight and value to all ratios, with no indication of which ratios may be the most important or what positive lessons we learn using different perspectives (a diachronic perspective - trend analysis over time - or a synchronic perspective - benchmarking at a point in time).

In the next section, we propose a statistical analysis with a diachronic perspective and synchronic perspective with the goal to demonstrate how this powerful tool could immediately make the situation more visible and, at the same time, create a basis for the analysis of causes in an integrated perspective (financial and social).

\section{Toward an Integrated Representation of Social Performance and Financial Performance: An Explorative Analysis}

This analysis, carried out across 2014 and 2015, aims to give a visual form to cause-and effect patterns on social and financial performance, thusly contributing to the construction of a systematic approach. Financial analysis, using cause-and-effect ratios, provides the most valuable contribution to the processing of data regarding the impact of social practices on stakeholder value (Castro and Chousa, 2006). We are not specifically looking into the "type" of relationship between social and financial performance, but rather we emphasize the worth of statistical analysis and its integration into traditional financial representations.

In order to investigate the relationships between CSP and CFP, we extracted a sample of companies from the csrhub.com database. This database includes CSR ratings for about 1,000 European companies and roughly 3,000 US companies. It is B Corp certified and it is part of GRI (Global Reporting Initiative), Carbon Disclosure (CDP), International Integrated Reporting Committee (IIRC) initiatives. It is also worth noting that Csrhub integrates data from different sources such as Asset4/Thomson Reuters; Carbon Disclosure Project (CDP); EIRIS; Governance Metrics International/Corporate Library; IW Financial; MSCI (ESG Intangible Value Assessment and ESG Impact Monitor); RepRisk; Trucost and Vigeo. This tool integrates many sources on different aspects of social performance, triangulating multiple data. Index value is based on the mean score across all these sources for each firm and is standardized across different countries and sectors.

Our sample consists of 275 firms, which were randomly selected within the Csrhub database. The analysis covers five years (from 2010 to 2014), with 1,375 firm-year observations.

For each firm, the database expresses social performance through four main ratios:

1. Community;

2. Employees;

3. Environment;

4. Governance.

The database also computes an "Overall" ratio, as a synthesis of the four above-mentioned ratios.

For each selected firm, we calculated economic and financial ratios, through the Orbis database (a Bureau van Dijk database). More specifically, ratios we analyzed are: ROE (Return on Equity); ROA (Return on Assets); EBITDA (Earnings Before Interest, Taxes, Depreciation and Amortization); Profit per employee ratio; Price earning ratio; Current ratio; Liquidity ratio; Solvency ratio; Cash flow; Total assets; Total assets per employee. These ratios are the most 
widely used in literature.

Through these ratios, we tried to capture several features of the CFP, namely the economic performance (ROE, ROA, EBITDA, Price earnings ratio; Profit per employees), the financial performance (Current ratio; Liquidity ratio; Solvency ratio; Cash flow) and the size (Total assets; Total assets per employees) of the investigated firms.

We investigated the relationship between CSP and CFP, expressed by the above-mentioned ratios, through a regression model. We analyzed the correlation between the four social ratios (Community; Employees; Environment; Governance) and the Overall ratio. Taking into account that a strong linear correlation between these ratios was found (see Figure 1), we decided running the regression model considering only the Overall ratio as the dependent variable.

Figure 1. Scatterplot social
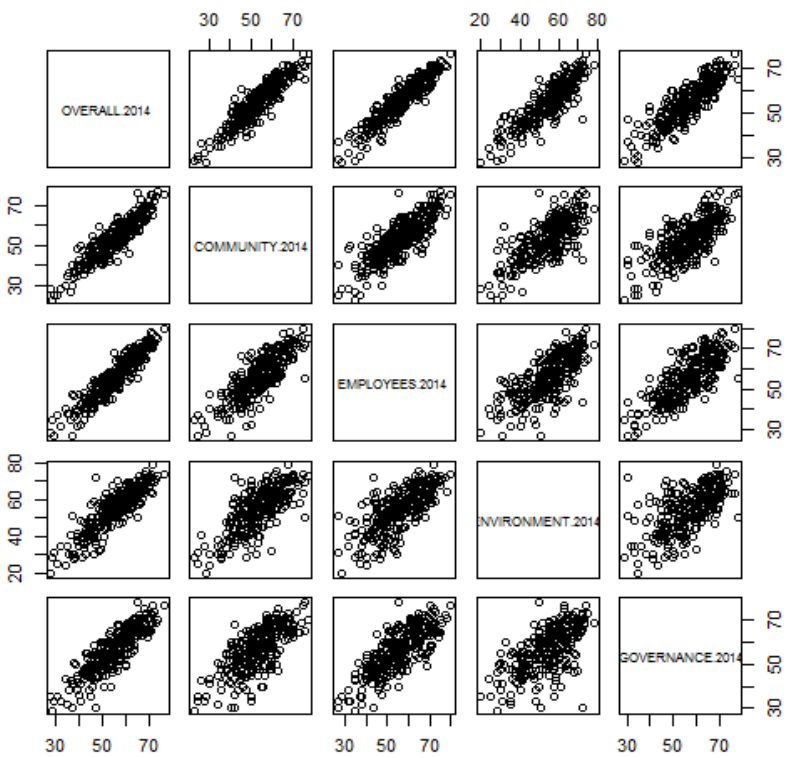

(year 2014)

From a methodological viewpoint, we adopted a panel analysis since estimators from a panel dataset seem to work best with longer time series (Verbeek, 2012).

Overall $=\alpha_{t i}+\beta_{1} R O E_{t i}+\beta_{2} R O A_{t i}+\beta_{3} E_{B I T D A_{t i}}+\beta_{4}$ Pro $_{-}$Emp $_{t i}+\beta_{5} P_{-} E_{t i}+\beta_{6} C R_{t i}+\beta_{7} L R_{t i}+\beta_{8} S R_{t i}+\beta_{9} C F_{t i}+$ $\beta_{10} T_{-} A s s_{t i}+\beta_{I I} T_{-} A s s_{-} E m p_{t i}+\varepsilon_{t i}$

Where: ROE (Return on Equity); ROA (Return on Assets); EBITDA (Earnings before Interest, Taxes, Depreciation and Amortization); Pro_Emp = Profit per employee ratio; P_E = Price earning ratio; CR = Current ratio; LR = Liquidity ratio; $\mathrm{SR}=$ Solvency ratio; $\mathrm{CF}=$ Cash flow; $\mathrm{T} \_$Ass $=$Total assets; $\mathrm{T} \_$Ass_Emp $=$Total assets per employee.

Given that previous studies provide contradictory results about the relationship between CSP and CFP, we were not able to predict the expected sign of the coefficient of each variable.

\section{Learning through Data: Investigating the Core of the Relation}

Table 1 illustrates the descriptive statistics of variables concerning social performance.

Table 1. Descriptive statistics of social scores

\begin{tabular}{|c|c|c|c|c|c|c|c|c|c|c|c|c|c|c|c|}
\hline & & 2010 & & & 2011 & & & 2012 & & & 2013 & & & 2014 & \\
\hline Variables & Mean & $M d$ & Std.dev & Mean & $M d$ & Std.dev & Mean & $M d$ & Std.dev & Mean & $M d$ & Std.dev & Mean & $M d$ & Std.dev \\
\hline Community & 53.96 & 54.50 & 6.36 & 56.88 & 57.00 & 7.20 & 54.49 & 55.00 & 6.90 & 51.81 & 52.00 & 7.88 & 53.56 & 54.00 & 10.30 \\
\hline Employees & 59.25 & 60.00 & 7.88 & 62.97 & 64.00 & & 56. & 57.00 & & & 55.00 & 9. & 55.82 & 55.50 & 10. \\
\hline Envi & 58.71 & 59.50 & 7.35 & 56.03 & 56.50 & 7.2 & 51.15 & 52.00 & 8.1 & 52.92 & 53.50 & 9.1 & 54.46 & 56.00 & 11.54 \\
\hline Gov & 55.02 & 56.50 & 6.65 & 56.72 & 57.00 & 7.38 & 56.40 & 57.00 & 6.99 & 56.05 & 56.50 & 8.4 & 56.78 & 58.00 & 10.08 \\
\hline Overall & 56.73 & 57.38 & 5.91 & 58.15 & 58.88 & 6.34 & 54.63 & 55.25 & 6.47 & 53.91 & 54.38 & 7.64 & 55.15 & 56.25 & 9.58 \\
\hline
\end{tabular}

In accordance with Csrhub's staff recommendations, we propose the following ranks:

- $0-25$ poor social performance;

- 25-40 low social performance;

- 41-59 good social performance;

- 60-70 strong social performance;

- 71-85 excellent social performance; 
- $86-100$ best in class.

Firms in our sample illustrate good social performance, as the mean values clearly illustrate; moreover, it is worth noting that in the first two years the Employees score median values are about 60, highlighting that more than half of the investigated companies pay great attention to this factor. However, in the following three years, it decreases, showing a median value of 55-57.

Both the mean and the median values of Community ratio are quite stable in the period covered by our analysis, even though some small variations can be observed, especially from 2010 to 2011. It should also be noted that standard deviation grows in the last year.

The Employees ratio increases in a remarkable way in 2011, while suffering a noteworthy reduction in the following years. A similar trend can be observed with the Environment ratio. Finally, the Governance ratio shows a rather stable trend during the five years.

Table 2 shows the descriptive statistics of variables concerning economic-financial ratios as well as size.

Table 2. Descriptive statistics of economic-financial performance and size

\begin{tabular}{|c|c|c|c|c|c|c|c|c|c|c|c|c|c|c|c|}
\hline & \multicolumn{3}{|c|}{2010} & \multicolumn{3}{|c|}{2011} & \multicolumn{3}{|c|}{2012} & \multicolumn{3}{|c|}{2013} & \multicolumn{3}{|c|}{2014} \\
\hline Variables & Mean & $M d$ & Std.dev & Mean & $M d$ & Std.dev & Mean & $M d$ & Std.dev & Mean & $M d$ & Std.dev & Mean & $M d$ & Std.dev \\
\hline ROE & 25.01 & 21.51 & 16.08 & 25.91 & 21.67 & 18.95 & 24.15 & 20.15 & 16.92 & 22.96 & 19.19 & 16.65 & 23.36 & 19.83 & 17.40 \\
\hline ROA & 10.74 & 8.53 & 7.43 & 10.83 & 8.91 & 7.69 & 10.23 & 8.09 & 7.45 & 9.97 & 7.79 & 7.36 & 9.84 & 8.05 & 7.81 \\
\hline EBITDA & 21.60 & 19.82 & 13.58 & 21.24 & 18.23 & 13.87 & 21.09 & 17.76 & 13.98 & 21.10 & 18.27 & 13.86 & 21.32 & 17.68 & 14.34 \\
\hline Pro_Emp & 70.63 & 34.07 & 105.78 & 73.62 & 32.22 & 125.44 & 71.29 & 32.22 & 125.44 & 69.88 & 34.68 & 113.19 & 67.56 & 30.77 & 107.21 \\
\hline P_E & 18.83 & 16.22 & 14.46 & 16.62 & 13.75 & 15.99 & 17.78 & 15.90 & 12.62 & 24.75 & 18.68 & 50.78 & 24.27 & 19.73 & 24.54 \\
\hline $\mathrm{CR}$ & 1.73 & 1.44 & 1.09 & 1.69 & 1.39 & 1.13 & 1.71 & 1.42 & 1.10 & 1.70 & 1.41 & 1.08 & 1.67 & 1.38 & 1.10 \\
\hline LR & 1.32 & 1.02 & 0.93 & 1.27 & 0.99 & 1.00 & 1.28 & 1.03 & 0.94 & 1.28 & 1.04 & 0.94 & 1.25 & 0.99 & 0.93 \\
\hline SR & 44.73 & 43.56 & 16.84 & 44.32 & 43.51 & 16.89 & 44.72 & 43.70 & 16.46 & 45.74 & 44.59 & 16.42 & 44.43 & 42.89 & 16.60 \\
\hline CF (th.) & 2,454 & 681 & 5,142 & 2,527 & 734 & 5,181 & 2,629 & 735 & 5,560 & 2,739 & 798 & 5,564 & 2,652 & 778 & 5,150 \\
\hline T_Ass (th.) & 22,069 & 6,717 & 40,728 & 23,310 & 6,864 & 44,200 & 25,073 & 7,317 & 51,871 & 26,210 & 7,578 & 51,871 & 25,955 & 7,844 & 51,078 \\
\hline T_Ass_Emp & 762.45 & 384.75 & 1,109 & 777.54 & 384.83 & 1,142 & 832.46 & 405.49 & 1,223 & 858.77 & 405.71 & 1,251 & 866.99 & 402.29 & 1,321 \\
\hline
\end{tabular}

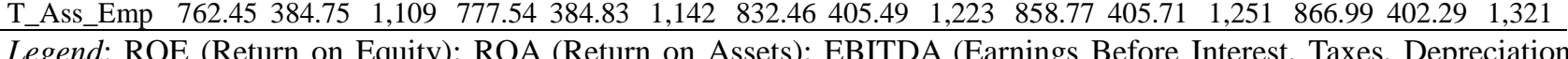
and Amortization); Pro_Emp (Profit per employee ratio); P_E (Price earning ratio); CR (Current ratio); LR (Liquidity ratio); SR (Solvency ratio); CF (Cash flow in thousands); T_Ass (Total assets in thousands); T_Ass_Emp (Total assets per employee).

Both ROE and ROA are quite stable in the first three years, denoting a visible reduction especially in 2013, probably due to the global financial crisis.

Generally, firms in our sample experienced positive financial performance, as the mean values of both Current ratio and Liquidity ratio clearly illustrate.

Having investigated descriptive statistics of these two ratio sets, we need to investigate the relationship between them to understand if there is a link between CSP and CFP. As stated above, since a strong linear correlation exists between each social ratio (Community, Employees, Environment and Governance) and the Overall ratio, we consider only this last measure of social performance in our analysis.

The following figures provide a picture of the relationship between the overall score, size, and the main economic and financial performance ratios. Through comparing the trends of both variables, we explored if such a relationship could be hypothesized.
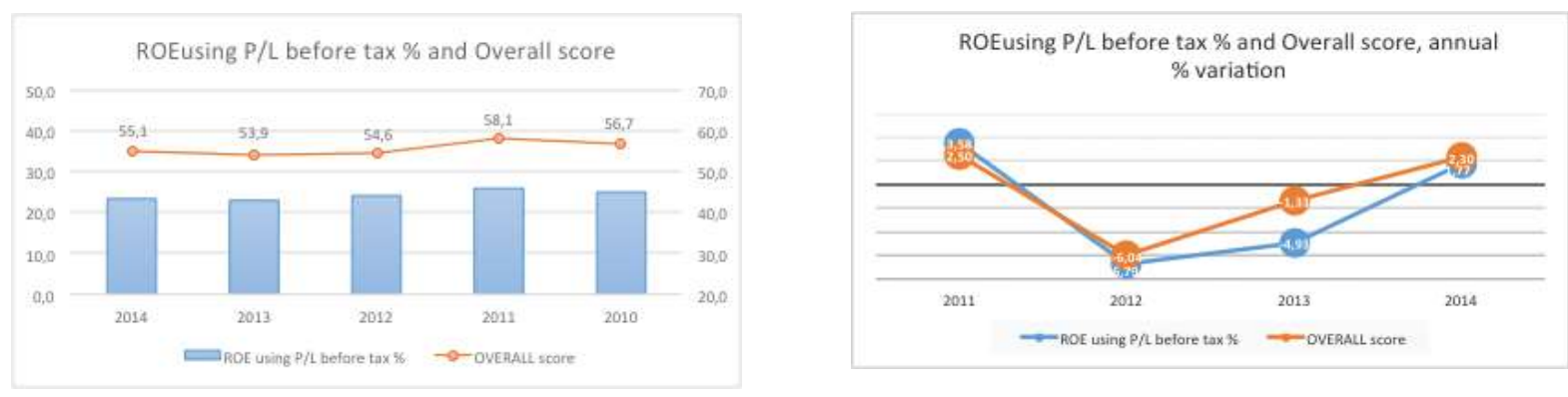

Figure 2. Trend of ROE and Overall score (annual \% variation) 

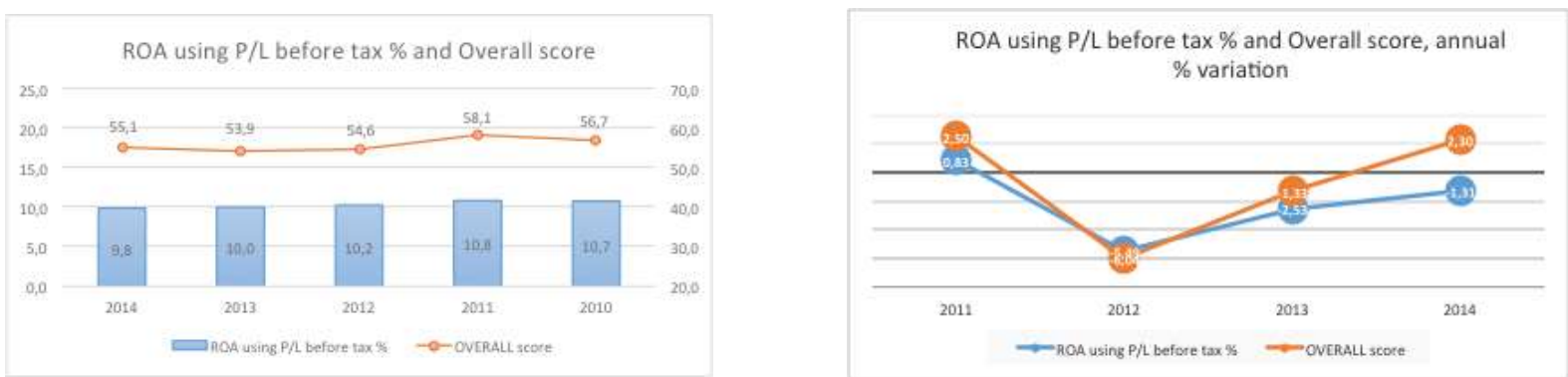

Figure 3. Trend of ROA and Overall score (annual \% variation)
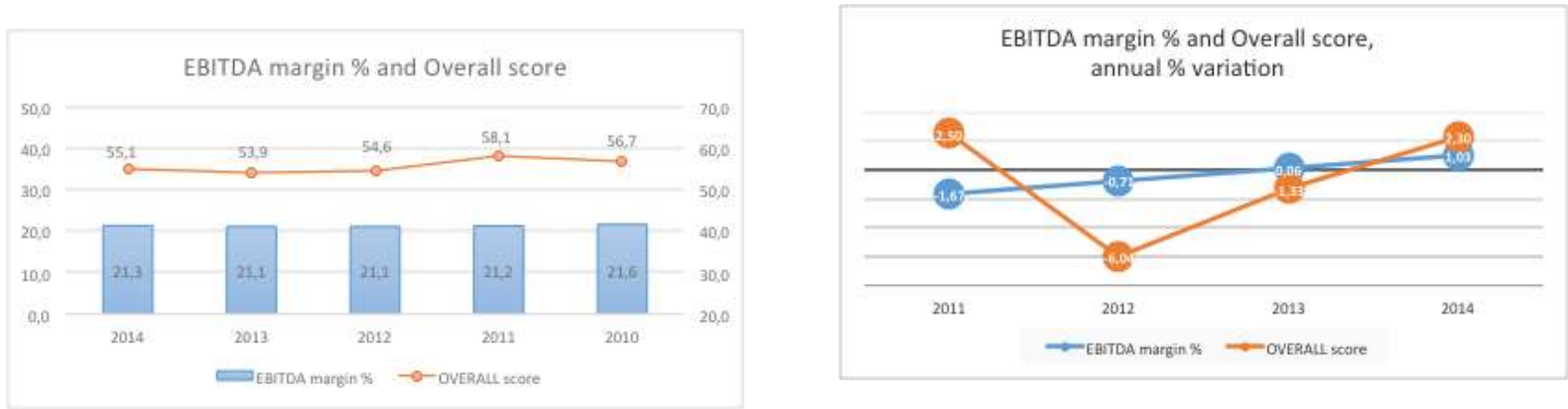

Figure 4. Trend of EBITDA and Overall score (annual \% variation)
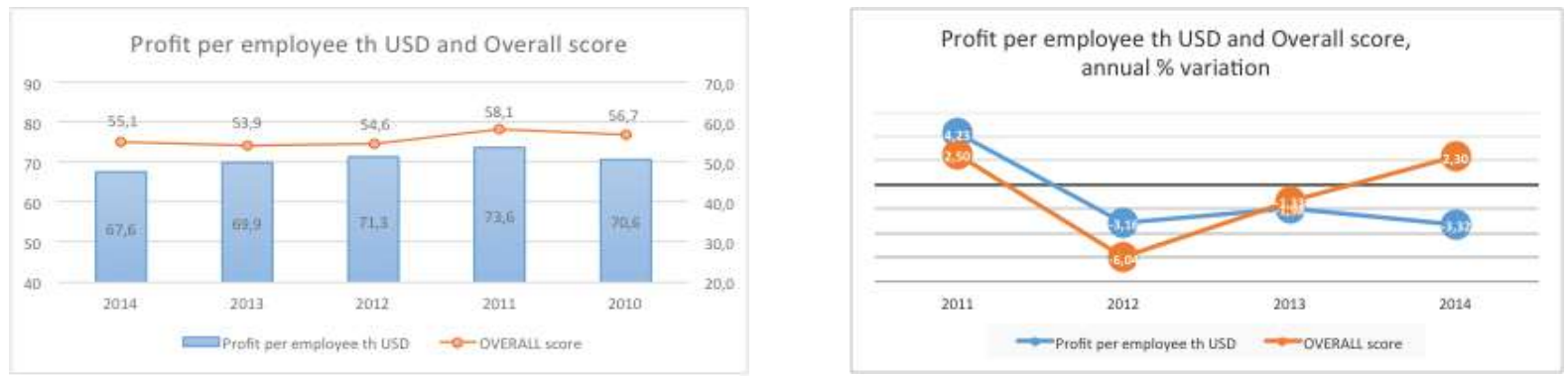

Figure 5. Trend of Profit per employee and Overall score (annual \% variation)

As we can easily observe, there is a clear link between economic performance ratios (ROE, ROA, EBITDA and Profit per employee), and the Overall score, since their movements occur close together (for example, when the economic performance improves, the social performance also improves). However, Figure no. 4 illustrates an opposite trend between the Overall score and EBITDA, especially from 2011 and 2012 (EBITDA improves while the Overall score decreases).
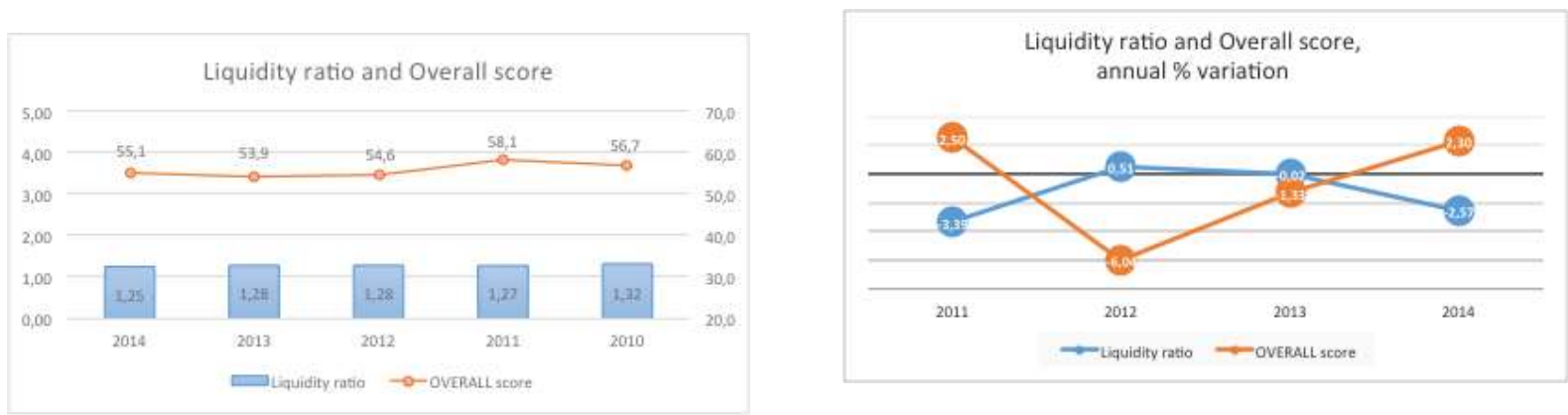

Figure 6. Trend of Liquidity ratio and Overall score (annual \% variation) 

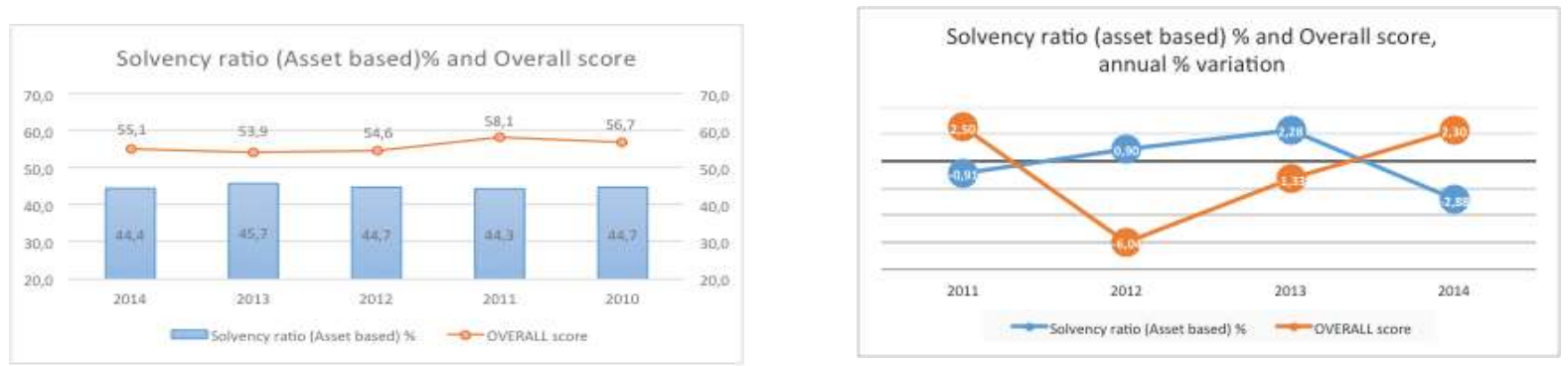

Figure 7. Trend of Solvency ratio and Overall score (annual \% variation)
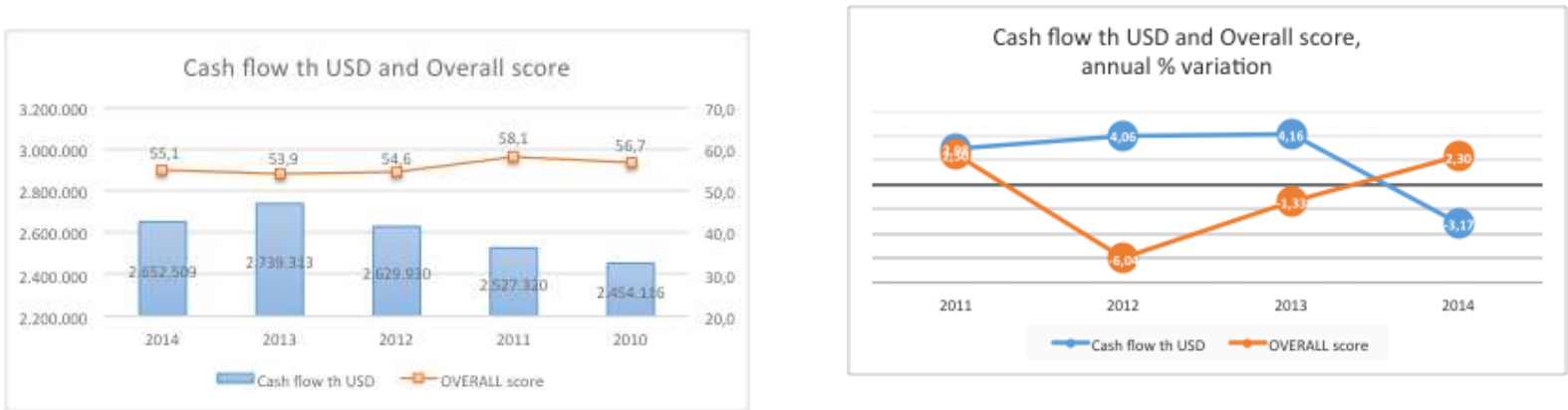

Figure 8. Trend of Cash Flow and Overall score (annual \% variation)

Figures no. 6, no. 7 and no. 8 compare the trends of financial performance (as expressed by the liquidity ratio, solvency ratio and cash flow) and social performance, expressed by the Overall ratio. In this case, we see an opposite trend, particularly accentuated in 2012 and 2014.
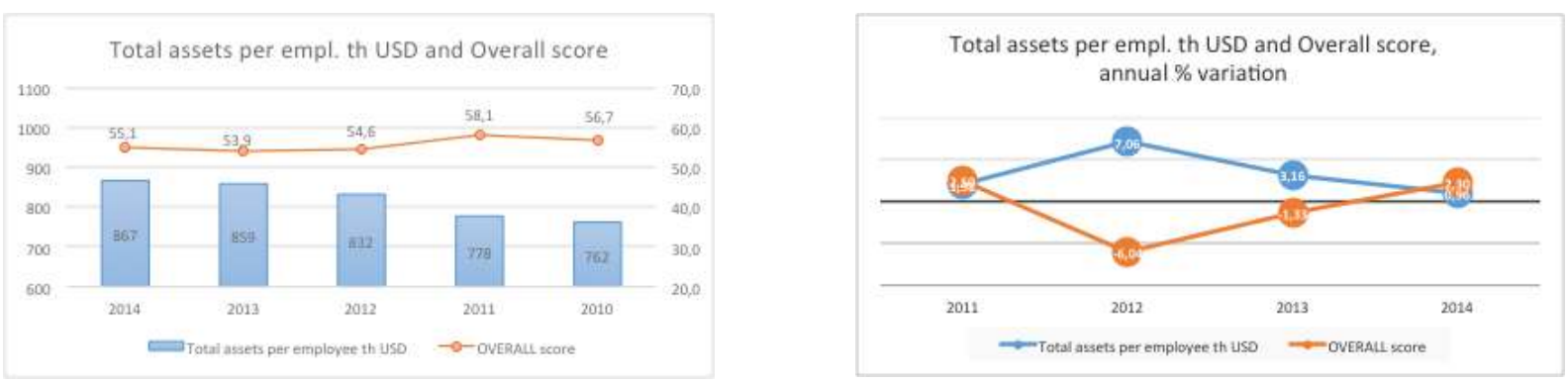

Figure 9. Trend of Total asset per employee and Overall score (annual \% variation)
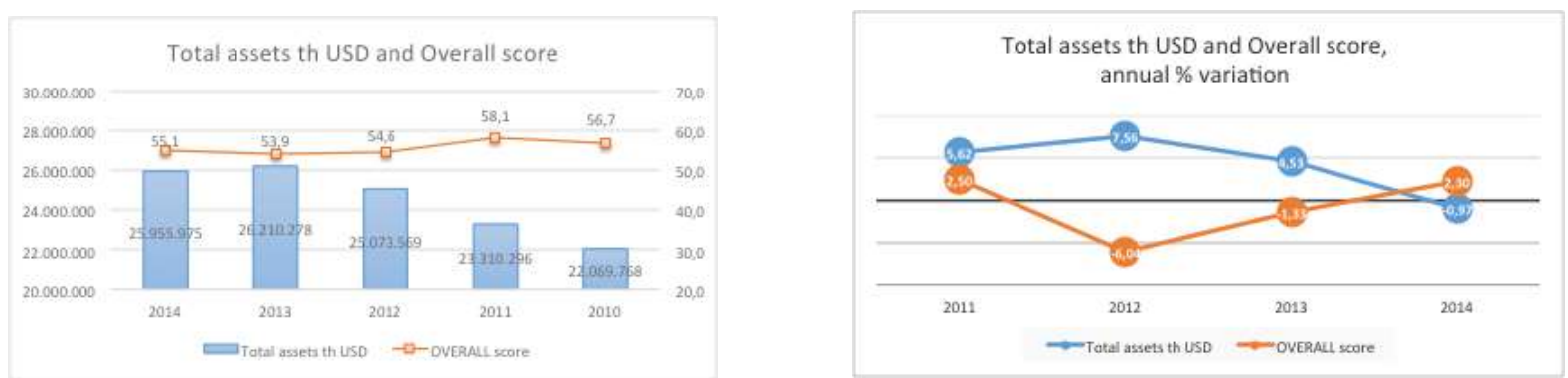

Figure 10. Trend of Total asset and Overall score (annual \% variation)

Finally, the last two figures (no. 9 and no. 10) show the relationship between size and social performance: also in this case, we can observe a similar path.

We assume firms that have accrued significant social performance may earn economic returns. Those firms with the highest social investments will exhibit good financial performance in the long term, while short-term investments could 
lower the financial ratios. That is to say, firms will increasingly get favorable returns on their social investments, just as firms replete with absorptive capacity earn more from their investments in knowledge (Barnett and Salomon, 2012).

In order to better investigate this hypothesized relationship, we implement a regression model where the Overall ratio is the dependent variable and the CFP's ratios are the independent variables.

However, first, we need to check for correlations between independent variables, as Table 4 illustrates.

Table 4. Correlation matrix

\begin{tabular}{|c|c|c|c|c|c|c|c|c|c|c|c|}
\hline & $R O E$ & $R O A$ & $C R$ & $L R$ & $S R$ & $P p E$ & TAssEmp & Ebitda & $T \_A s s$ & $C F$ & $P E$ \\
\hline$R O E$ & 1 & & & & & & & & & & \\
\hline$R O A$ &, $752^{* *}$ & 1 & & & & & & & & & \\
\hline$C R$ &,- 025 &, $296^{* * *}$ & 1 & & & & & & & & \\
\hline$L R$ &,$- 065^{*}$ & $241^{* * *}$ &, $905^{* *}$ & 1 & & & & & & & \\
\hline$S R$ &,$- 192^{* *}$ & $379^{* *}$ & $603^{* *}$ &, $577^{* *}$ & 1 & & & & & & \\
\hline$P p E$ & $209^{* * *}$ & $202^{* * *}$ &, 045 & $105^{* *}$ &,- 002 & 1 & & & & & \\
\hline TAssEmp &,$- 069^{*}$ &,$- 153^{* *}$ &,$- 101^{* * *}$ &,- 017 &,$- 167^{* * *}$ &, $795^{* *}$ & 1 & & & & \\
\hline Ebitda & $231^{* *}$ &, $318^{* *}$ &, $076^{* *}$ &, $186^{* * *}$ &, $098^{* * *}$ & $601^{* * *}$ &, $539^{* *}$ & 1 & & & \\
\hline T_Ass &,- 035 &,$- 122^{* * *}$ &,$- 210^{* *}$ &,$- 181^{* *}$ &,$- 178^{* * *}$ & $130^{* * *}$ & $166^{* * *}$ & 044 & 1 & & \\
\hline$\overline{C F}$ &, $079^{* *}$ & ,018 &,$- 174^{* *}$ &,$- 153^{* *}$ &,$- 097^{* * *}$ & $204^{* * *}$ &, $127^{* *}$ &, $110^{* *}$ & ,925 & 1 & \\
\hline$P E$ &,$- 141^{* *}$ &,$- 117^{* * *}$ &, 006 & ,024 &, $090^{* * *}$ &,$- 102^{* *}$ &,- 032 &,$- 093^{* *}$ &,$- 095^{* * *}$ &,- 105 & 1 \\
\hline
\end{tabular}

Legend: ROE (Return on Equity); ROA (Return on Assets); EBITDA (Earnings Before Interest, Taxes, Depreciation and Amortization); Pro_Emp (Profit per employee ratio); $P_{-} E$ (Price earning ratio); CR (Current ratio); LR (Liquidity ratio); SR (Solvency ratio); CF (Cash flow in thousands); TAss (Total assets in thousands); TAssEmp (Total assets per employee)

\section{**; *Correlation is significant at the 0.01 and 0.05 level (2-tailed)}

Generally, previous literature (Niemi, 2005), suggests removing variables whose correlation coefficient is greater than 0.8, seen as a threshold level; accordingly, since a strong correlation (higher than 0.9) can be observed between Current ratio and Liquidity ratio as well as between Cash flow and Total assets, we excluded both Current ratio and Cash Flow. Therefore, our final model is:

Overall $=\alpha_{t i}+\beta_{1} R O E_{t i}+\beta_{2} R O A_{t i}+\beta_{3} E B I T D A_{t i}+\beta_{4} P r o \_E m p_{t i}+\beta_{5} P_{-} E_{t i}+\beta_{6} L R_{t i}+\beta_{7} S R_{t i}+\beta_{8} T \_A s s_{t i}+$ $\beta_{9} T_{-} A s s_{-} E m p_{t i}+\varepsilon_{t i}$

Table 5 shows the results of the regression model.

Table 5. Regression model results

\begin{tabular}{|c|c|c|c|c|c|}
\hline & Coefficient & Std. error & Stat $t$ & p-value & \\
\hline const & 60,1786 & 1,1656 & 51,6288 & $<0,0001$ & $* * *$ \\
\hline ROE & $-0,0205099$ & 0,0305115 & $-0,6722$ & 0,5016 & \\
\hline ROA & 0,0977172 & 0,0764583 & 1,2780 & 0,2015 & \\
\hline EBITDA_margin & $-0,0588191$ & 0,0210054 & $-2,8002$ & 0,0052 & $* * *$ \\
\hline Profit_per_employee & 0,000624767 & 0,00375183 & 0,1665 & 0,8678 & \\
\hline Price_earning_ratio & 0,0108371 & 0,00797635 & 1,3587 & 0,1745 & \\
\hline Liquidity_ratio & 0,29562 & 0,276913 & 1,0676 & 0,2860 & \\
\hline Solvency_ratio & $-0,113641$ & 0,0249494 & $-4,5549$ & $<0,0001$ & $* * *$ \\
\hline Total_Assets & $1,15477 \mathrm{e}-08$ & $4,69524 \mathrm{e}-09$ & 2,4594 & 0,0141 & $* *$ \\
\hline Total_Assets_per_employee & 0,000498911 & 0,000368816 & 1,3527 & 0,1764 & \\
\hline $\begin{array}{ll}R^{2} \\
F(9\end{array}$ & 0,287037 & & & & \\
\hline$F(9,1084)$ & 8.24788 & & & $5,08104 e-1$ & \\
\hline
\end{tabular}

According to the above-mentioned classification of our model's ratios into three dimensions (economic performance, financial performance and size of a company), results show that three variables concerning these three features (respectively: EBITDA, Solvency ratio and Total Assets) are statistically significant.

However, coefficients of these variables are quite low, expressing a moderate impact on the social performance, suggesting that social performance needs to be investigated with regard also to other variables. Additionally, a more in-depth analysis could provide more detailed information: as a relevant example, some economic-financial ratios (such as ROE and ROI) could be analyzed by investigating the role of their components as well as their mutual relationship, to better define the potential impact on CSP. This analysis could be carried out at a firm level, due to the availability of integrated databases.

\section{Discussions and Conclusions}

This study has investigated the relationship between traditional financial-economic performance and social performance, an intriguing topic that has attracted the interest of many researchers. Our analysis aims to support the idea that measuring the impact of social performance is not an easy task and that other factors should be taken into account. 
In the literature, several studies have obtained contradictory results. Therefore, these contrasting findings create a confusing picture (Margolis and Walsh, 2003; Barnett, 2007), highlighting that both positions might be correct, depending on the timescale (Barnet and Salomon, 2012).

Indeed, our findings show that economic-financial ratios as well as the firm size affect social performance; still, they also suggest the need to broaden the horizon through considering the potential impact of other variables.

The aggregate list of ratios/variables could be infinite, but a first analysis is useful to focus on those that are relevant, depending on sector membership and company size; such an analysis should be conducted through a double learning process combining a deductive and inductive approach (placing emphasis on specific data and the application of statistical methods) (Castro and Chousa, 2006).

The analysis of data at a single point in time (synchronic perspective) and the selection of more interesting variables, allowed us to select the most powerful trends on our timeline (diachronic perspective) and discover some relationships between variables (one by one).

The financial analysis could be enriched by taking into account the moderate effect of such variables on the impact of financial investment on social performance and vice versa. Future analyses should attempt to sort out the degree to which financial benefits from CSP come through decreased costs, perhaps from improved efficiency at providing social programs, rather than the ability to increase revenues.

The pyramid of financial ratios (Courtis, 1978; Bayldon et al., 1984), with a hierarchical structure that links measures at different organizational levels, could help identifying the sources of strength and weakness in current performance, with a focus on 'value drivers'. This notion is combined with the indication of future performance and encouraging long term planning ${ }^{2}$.

But, in our opinion, ratio analysis and statistical cause-and-effect validation are not alternatives for developing the financial analysis of sustainability and reporting.

According to Castro and Chousa (2006), through constant testing and refinement in the real world, the critical relationship between the key factors of financial, economic and social performance will be identified and organized for immediate use.

The company's directors may have to explain to their shareholders that reducing or increasing the economic and financial ratios compensated the increase in a social ratio. Thus, managers should take heed of more intermediate measures of the returns of social responsibility and constantly seek to improve ways of measuring how a firm's socially responsible (and irresponsible) actions facilitate the transformation of social responsibility into profit. Companies will be more economically successful if they improve their social performance in the most economical/financial manner, combining the analysis of actual performance with a broad understanding of future trends and stakeholder expectations.

Firms, breaking down the system of critical variables, will have the possibility to understand and leverage the value of social investment into financial returns. Indeed, CSP and CFP are neither purely positive nor negative. Firms gain all the benefits only after tipping a critical point (Barnett and Salomon, 2012). Firms exhaust profitable social investment opportunities by developing capabilities that allow some to better meet the market demand for social responsibility. But also by lowering operating costs through CSP (Barnett and Salomon, 2012).

Our results indicate that improving social performance necessitates a learning process, to increase the likelihood of benefitting from investments in social responsibility (also scarifying financial performance sometimes). Like Castro and Chousa (2006), we support the idea of combining a deductive approach, based on the (theoretical) rules of financial ratio analysis to derive rules that explain how changes in specific cause ratios will influence the effect ratios, with an inductive approach, characterized by an emphasis on specific data and the application of statistical methods. Grouping financial ratios are central to this approach, along with the identification of relevant ratios and the relationships between them; this process will explain the company's strengths and weaknesses to help guide its strategic decision making processes. These rules will be based on the time series and benchmark (cross industries, dimensions, etc.) analysis of the relevant ratios, and the analysis of the cause effect chains that link them.

\section{References}

Bayldon, R., Woods, A., \& Zafiris, N. (1984). A note on the 'pyramid' technique of financial ratio analysis of firms' performance. Journal of Business Finance and Accounting, 11(1), 99-106. https://doi.org/10.1111/j.1468-5957.1984.tb00060.x

Barnett, M. L. (2007). Stakeholder influence capacity and the variability of financial returns to corporate social

${ }^{2}$ Other practices, like Kaplan and Norton's strategy mapping, give a visual form to cause-and-effect chains, linking actions through learning and growth, internal processes and customer perspectives to financial results. 
responsibility. Academy of Management Review, 32(3), 794-816. https://doi.org/10.5465/AMR.2007.25275520

Barnett, M. L., \& Salomon, R. M. (2012). Does it Pay to Be Really Good? Addressing the Shape of the Relationship between Social and Financial Performance. Strategic Management Journal, 33, 1304-1320. https://doi.org/10.1002/smj.1980

Belkaoui, A. (1976). The Impact of the Disclosure of the Environmental Effects of Organizational Behavior on the Market. Financial Management, 5(4), 26-31. https://doi.org/10.2307/3665454

Brammer, S., \& Millington, A. (2008). Does it pay to be different? An analysis of the relationship between corporate social and financial performance. Strategic Management Journal, 29(12), 1325-1343. https://doi.org/10.1002/smj.714

Castro, N. R., \& Chousa, J. P. (2006). An Integrated Framework for the Financial Analysis of Sustainability. Business Strategy and the Environment, 15, 322-333. https://doi.org/10.1002/bse.539

Cochran, P., \& Wood, R. (1984). Corporate social responsibility and financial performance. Academy of Management Journal, 27, 42-56. https://doi.org/10.2307/255956

Courtis, J. (1978). Modelling a financial ratios categoric framework. Journal of Business Finance and Accounting, 5(4), 371-386. https://doi.org/10.1111/j.1468-5957.1978.tb01059.x

de Villiers, C., Rinaldi, L., \& Unerman, J. (2014). Integrated Reporting: Insights, gaps and an agenda for future research. Accounting, Auditing \& Accountability Journal, 27(7), 1042-1067. https://doi.org/10.1108/AAAJ-06-2014-1736

Elkington, J. (1994). Towards the Sustainable Corporation: Win-Win-Win Business Strategies for Sustainable Development. California Management Review, 36(2), 90-100. https://doi.org/10.2307/41165746

Freeman, R. (1984). Strategic Management: A Stakeholder Perspective. Pitman: Boston, MA.

Friedman, M. (1970). The social responsibility of business is to increase its profits. New York Times Magazine, 3 September, 122-126.

Hillman, A. J., \& Keim, G. D. (2001). Shareholder value, stakeholder management, and social issues: what's the bottom line? Strategic Management Journal, 22(2), 125-139. https://doi.org/10.1002/1097-0266(200101)22:2<125::AID-SMJ150>3.0.CO;2-H

Margolis, J., \& Walsh, J. (2003). Misery loves company: rethinking social initiatives by business. Administrative Science Quarterly, 48, 268-305. https://doi.org/10.2307/3556659

McWilliams, A., \& Siegel, D. (2000). Corporate social responsibility and financial performance: correlation or misspecification?' Strategic Management Journal, 21(5), 603-609. https://doi.org/10.1002/(SICI)1097-0266(200005)21:5<603::AID-SMJ101>3.0.CO;2-3

Niemi, L. (2005). Audit effort and fees under concentrated client ownership: Evidence from four international audit firms. The International Journal of Accounting, 40, 303-323. https://doi.org/10.1016/j.intacc.2005.09.006

Orlitzky, M., Schmidt, F., \& Rynes, S. (2003). Corporate social and financial performance: a meta-analysis. Organization Studies, 24, 403-441. https://doi.org/10.1177/0170840603024003910

Patten, D. (1991). Exposure, legitimacy, and social disclosure. Journal of Accounting and Public Policy, 10, 297-308. https://doi.org/10.1016/0278-4254(91)90003-3

Porter, M., \& van der Linde, C. (1995). Green and competitive. Harvard Business Review, 73(5), 121-134.

Sturdivant, F. D., \& Ginter, J. L. (1977). Corporate Social Responsiveness. California Management Review, 19(3), 30-39. ttps://doi.org/10.2307/41164709

Vance S. (1975). Are socially responsible corporations good investment risks? Management Review, 64, 18-24.

Verbeek, M. (2012). A Guide to Modern Econometrics. 4th ed. Wiley \& Sons, Chichester.

Wicks, A. C., Berman, S. L., \& Jones, T. M. (1999). The structure of optimal trust: moral and strategic implications. Academy of Management Review, 24(1), 99-116.

Wright, P., \& Ferris, S. P. (1997). Agency conflict and corporate strategy: the effect of divestment on corporate value. Strategic Management Journal, 18(1), 77-83. https://doi.org/10.1002/(SICI)1097-0266(199701)18:1<77::AID-SMJ810>3.0.CO;2-R

\section{Copyrights}

Copyright for this article is retained by the author(s), with first publication rights granted to the journal.

This is an open-access article distributed under the terms and conditions of the Creative Commons Attribution license which permits unrestricted use, distribution, and reproduction in any medium, provided the original work is properly cited. 